al Kimiya, Vol. 2, No. 1, Juni 2015

\title{
ISOLASI DAN KARAKTERISASI AMILASE DARI BIJI DURIAN (DURIO SP.)
}

\section{Lela SRIWAHyuni, Tina DEWI RoSAHDI,* DAN ASEP SuPRIADin.}

Jurusan Kimia, Fakultas Sains dan Teknologi, UIN Sunan Gunung Djati Bandung, Jl. A.H. Nasution No. 105 Cipadung, Bandung 40614

* email korespondensi: tina_dr@uinsgd.ac.id

\begin{abstract}
ABSTRAK. Amilase merupakan enzim yang mampu menghidrolisis ikatan glikosidik dalam molekul pati. Amilase berasal dari berbagai sumber yaitu, mikroorganisme, tumbuhan, dan manusia. Penggunaan biji durian sebagai sumber amilase merupakan bentuk pemanfaatan limbah. Biji durian dipilih sebagai sumber amilase karena mengandung amilum. Karbohidrat yang terdapat pada biji durian memungkinkan adanya amilase. Tujuan umum dari penelitian ini adalah untuk mengisolasi dan mengkarakterisasi amilase dari biji durian. Amilase diekstraksi dengan buffer fosfat $50 \mathrm{mM}$ (pH 7,5). Amilase difraksinasi dengan metode salting out menggunakan $\left(\mathrm{NH}_{4}\right)_{2} \mathrm{SO}_{4}$ dan dimurnikan dengan metode didialisis. Aktivitas amilase dari biji durian (Durio sp.) ditentukan dengan menggunakan metode Fuwa dan konsentrasi protein diukur dengan metode Bradford. Aktivitas spesifik yang paling tinggi diperoleh pada tingkat kejenuhan $60 \%$ sebesar $1959,75 \mathrm{U} / \mathrm{mg}$. pH optimum amilase berada pada pH 6 sedangkan suhu optimumnya berada pada suhu $40^{\circ} \mathrm{C}$.
\end{abstract}

Kata-kata kunci: Amilase, biji durian, salting out, dialisis, aktivitas spesifik, metode Fuwa, metode Bradford

\section{Latar Belakang}

Kebutuhan enzim di Indonesia masih tergantung pada impor. Salah satu enzim yang paling banyak digunakan di industri yaitu amilase. Amilase adalah enzim pendegradasi pati yang digunakan di industri makanan dan minuman, tekstil, detergen, kertas, farmasi dan lain-lain. Lembaga Ilmu Pengetahuan Indonesia (LIPI) melaporkan bahwa sejak tahun 70-an amilase yang digunakan di industri tekstil di Bandung-Jawa Barat, jumlahnya tidak kurang dari 4 ton per bulan atau sekitar 2-3 juta dolar Amerika.

Ada tiga macam amilase, yaitu $\alpha$-amilase, $\beta$-amilase dan $\gamma$-amilase. $\alpha$-Amilase terdapat dalam saliva dan pankreas. Enzim ini menghidrolisis ikatan 1-4 glikosidik yang terdapat dalam amilum dan disebut endoamilase sebab enzim ini memecah bagian dalam atau bagian tengah molekul amilum. $\beta$ Amilase terutama terdapat pada tumbuhan dan dinamakan eksoamilase sebab memecah dua unit glukosa yang terdapat pada ujung molekul amilum secara berurutan sehingga pada akhirnya terbentuk maltosa. $\gamma$-Amilase terdapat dalam hati. Enzim ini dapat memecah ikatan 14 dan 1-6 pada glikogen dan menghasilkan glukosa. ${ }^{[1]}$

Pada penelitian ini, amilase diisolasi dari biji durian. Biji durian (Durio sp.) dipilih sebagai sumber amilase karena mempunyai kadar amilum yang cukup tinggi. Kadar amilum sebanyak $43,6 \%$ untuk biji durian segar dan $46,2 \%$ untuk biji yang sudah masak. ${ }^{[2]}$ Tingginya kadar karbohidrat pada biji durian memungkinkan adanya amilase.

\section{Metode Penelitian}

\section{Ekstraksi Amilase}

Biji durian dibersihkan, dan dikeringkan, Kemudian 300 gram biji durian diblender dengan ditambahkan $600 \mathrm{~mL}$ buffer fosfat $50 \mathrm{mM} \mathrm{pH} \mathrm{7,5} \mathrm{selama} 10$ menit. Bubur biji durian disaring dan didekantasi sehingga terpisah antara ekstrak dan endapan pati. Ekstrak selanjutnya disentrifugasi dengan putaran 4000 rpm selama 15 menit. $^{[4]}$ Supernatan yang diperoleh diuji aktivitas dan konsentrasi amilasenya. Supernatan yang dihasilkan disebut sebagai ekstrak kasar.

\section{Uji Aktivitas dan Konsentrasi Amilase dari ekstrak kasar}

Supernatan diuji aktivitasnya menggunakan metode Fuwa. Sebanyak $50 \mu \mathrm{L}$ larutan pati $3 \%$ dalam buffer fosfat $50 \mathrm{mM} \mathrm{pH}$ 7,5, ditambah $50 \mu \mathrm{L}$ larutan enzim dan diinkubasi pada suhu $50{ }^{\circ} \mathrm{C}$ selama 10 menit. 
Campuran ditambah $50 \mu \mathrm{L} \mathrm{HCl} 1 \mathrm{M}, 50 \mu \mathrm{L}$ larutan iodium (mengandung $2 \% \mathrm{KI}$ dan $0,2 \%$ I2) dan diencerkan dengan akuades hingga volume $1 \mathrm{~mL}$. Absorbansinya diukur pada panjang gelombang $600 \mathrm{~nm} .{ }^{[5]}$

Konsentrasi amilase diuji dengan metode Bradford. Sebanyak $500 \mu \mathrm{L}$ ekstrak enzim dan $500 \mu \mathrm{L}$ pereaksi Bradford divortex, diinkubasi selama 5-10 menit pada suhu ruang. Kemudian diukur pada absorbansi $595 \mathrm{~nm} .{ }^{[6]}$ Konsentrasi enzim ditentukan berdasarkan standar konsentrasi protein. Standar konsentrasi protein yang digunakan yaitu BSA (Bovine Serume Albumin).

\section{Fraksinasi Amilase dengan Salting Out}

Larutan enzim dalam tabung disiapkan. Garam ammonium sulfat ditambahkan hingga mencapai $50 \%$ jenuh. Campuran diaduk dan dibiarkan selama lima menit pada suhu kamar, kemudian disentrifugasi selama 15 menit dengan kecepatan $4000 \mathrm{rpm}$. Supernatan dipindahkan ke dalam tabung yang baru. Endapan yang terbentuk disebut fraksi 50\% ammonium sulfat jenuh. Endapan dilarutkan dengan buffer fosfat $50 \mathrm{mM}$ pH 7,5. Garam ammonium sulfat ditambahkan ke dalam supernatan dari tahap sebelumnya hingga mencapai $55 \%$ jenuh. Campuran diaduk dan dibiarkan selama lima menit pada suhu kamar. Campuran disentrifugasi selama 15 menit. Supernatan dipindahkan ke dalam tabung baru. Endapan yang terbentuk disebut fraksi 55\% ammonium sulfat jenuh. Endapan dilarutkan dengan buffer fosfat $50 \mathrm{mM} \mathrm{pH} \mathrm{7,5.} \mathrm{Garam}$ ammonium sulfat ditambahkan ke dalam supernatan dari tahap sebelumnya hingga mencapai $60 \%$ jenuh. Campuran diaduk dan dibiarkan selama lima menit pada suhu kamar. Campuran disentrifugasi selama 15 menit. Supernatan dipindahkan ke dalam tabung baru. Endapan yang terbentuk disebut dengan fraksi $60 \%$ ammonium sulfat jenuh. Endapan dilarutkan dengan buffer fosfat $50 \mathrm{mM} \mathrm{pH} \mathrm{7,5.}$ Setiap fraksi ammonium sulfat yang dihasilkan didialisis dengan menggunakan buffer fosfat 50 $\mathrm{mM}$ pH 7,5 selama 3 jam (dengan mengganti larutan buffer fosfat setiap 1 jam sekali). ${ }^{[3]}$

\section{Pemurnian Amilase dengan Dialisis}

Larutan enzim tiap fraksi dimasukkan ke dalam masing-masing membran selofan yang berbeda. Selama dialisis volume larutan dapat meningkat, maka pengisian kantung jangan terlalu penuh. Proses dialisis dilakukan dengan merendam kantong selofan berisi larutan enzim dalam buffer fosfat $50 \mathrm{mM}$ pH 7,5 sambil diaduk menggunakan magnetic stirer pada suhu $5^{\circ} \mathrm{C}$. Tiap 1 jam sekali larutan buffer fosfat harus diganti selama 3 jam. ${ }^{[7]}$ Larutan enzim yang telah mengalami dialisis, diuji kembali aktivitas dan konsentrasi amilasenya. Prosedur yang digunakan sama dengan uji aktivitas dan konsentrasi amilase dari ekstrak kasar.

\section{Karakterisasi Enzim Amilase}

pH Optimum

Sebanyak $50 \mu \mathrm{L}$ larutan pati $3 \%$ dalam buffer fosfat $50 \mathrm{mM}$ (pH 5, 6, dan 7) ditambah $50 \mu \mathrm{L}$ larutan enzim dan diinkubasi pada suhu $50{ }^{\circ} \mathrm{C}$ selama 10 menit. Campuran ditambah 50 $\mu \mathrm{L} \quad \mathrm{HCl} 1 \mathrm{M}, 50 \mu \mathrm{L}$ larutan iodium (mengandung 2\% KI dan $0,2 \% \quad \mathrm{I}_{2}$ ) dan diencerkan dengan akuades hingga volume 1 $\mathrm{mL}$. Absorbansinya diukur pada panjang gelombang $600 \mathrm{~nm} .^{[5]}$

\section{Suhu Optimum}

Sebanyak $50 \mu \mathrm{L}$ larutan pati $3 \%$ dalam buffer fosfat $50 \mathrm{mM} \mathrm{pH} \mathrm{7,5,} \mathrm{ditambah} 50 \mu \mathrm{L}$ larutan enzim dan diinkubasi pada suhu $(30,40$, 50, 60, dan $70^{\circ} \mathrm{C}$ ) selama 10 menit. Campuran ditambah $50 \mu \mathrm{L} \mathrm{HCl} 1 \mathrm{M}, 50 \mu \mathrm{L}$ larutan iodium (mengandung 2\% KI dan 0,2\% $\mathrm{I}_{2}$ ) dan diencerkan dengan akuades hingga volume 1 $\mathrm{mL}$. Absorbansinya diukur pada panjang gelombang $600 \mathrm{~nm} .{ }^{[5]}$

\section{Hasil dan Pembahasan}

\section{Ekstraksi Amilase dari Biji Durian}

Larutan buffer fosfat dengan $\mathrm{pH}$ 7,5 digunakan dalam proses ekstraksi karena dapat menghindari terjadinya inaktivasi enzim akibat $\mathrm{pH}$ yang berubah. Enzim akan mengalami denaturasi jika pelarut yang digunakan berupa larutan asam, basa, atau pelarut organik. Denaturasi ini menyebabkan enzim menjadi tidak aktif atau tidak dapat bekerja. ${ }^{[11]}$

Proses isolasi enzim dilakukan pada kondisi dingin untuk menjaga enzim agar tidak terdenaturasi. Campuran disentrifugasi dengan kecepatan 4000 rpm selama 15 menit, sampai terpisah antara endapan dan supernatan. 
Supernatan yang diperoleh selanjutnya disebut dengan ekstrak kasar.

Ekstrak enzim kasar yang dihasilkan diuji aktivitas dan kadar proteinnya. Hasil penentuan aktivitas amilase ekstrak kasar dapat dilihat pada Tabel 1.

Berdasarkan Tabel 1 aktivitas spesifik amilase pada supernatan keruh lebih besar dibanding dengan aktivitas spesifik amilase pada supernatan bening. Hal ini disebabkan jumlah amilase yang terisolasi pada supernatan keruh lebih banyak daripada supernatan bening, sehingga aktivitas spesifiknya lebih besar. Oleh sebab itu, supernatan keruh dipilih sebagai ekstrak enzim yang selanjutnya melalui tahap fraksinasi dan dialisis.

\section{Fraksinasi dengan Ammonium Sulfat (Salting out)}

Ekstrak enzim kasar hasil isolasi dari biji durian difraksinasi dengan garam ammonium sulfat pada beberapa tingkat kejenuhan. Penambahan garam ammonium sulfat akan menyebabkan ion garam menarik molekul air yang mengelilingi protein, hal ini mengakibatkan peningkatan interaksi hidrofobik sesama molekul protein dan menyebabkan penurunan kelarutan protein. Peningkatan reaksi elektrostatik dapat pula menyebabkan penurunan gaya tolak-menolak di antara molekul protein sehingga kelarutan protein menurun dan terjadi pengendapan. ${ }^{[8]}$
Pada Tabel 2 dapat dilihat pengaruh konsentrasi garam ammonium sulfat terhadap aktivitas amilase.

Pada saat ekstraksi, pelarut yang digunakan berupa buffer fosfat $\mathrm{pH} \quad 7,5$ sedangkan rentang $\mathrm{pH}$ yang baik untuk mengendapkan protein berada pada $\mathrm{pH} 4,8-6,3$ (titik isoelektrik) sehingga dipilih garam yang dapat sedikit menurunkan $\mathrm{pH}$ larutan. Garam ammonium sulfat merupakan garam yang bersifat asam, sehingga penambahan garam ammonium menyebabkan penurunan $\mathrm{pH}$ larutan enzim hingga mencapai titik isoelektriknya. Pada titik isolelektrik interaksi protein dengan protein lebih kuat dibandingkan dengan interaksi protein dengan air. Akibatnya kelarutan protein akan menurun dan mengendap.

Aktivitas amilase tertinggi terdapat pada tingkat kejenuhan $60 \%$, yaitu dengan kejenuhan tertinggi. Hal ini disebabkan adanya ion garam yang menjadi aktivator enzim yang dapat meningkatkan aktivitas enzim.

\section{Dialisis}

Tahap akhir setelah fraksinasi dengan garam yaitu dialisis larutan enzim dalam membran selofan. Dialisis bertujuan untuk menghilangkan garam ammonium sulfat (desalting). Proses dialisis dilakukan dengan merendam kantong selofan yang berisi larutan enzim dalam buffer fosfat $50 \mathrm{mM} \mathrm{pH} \mathrm{7,5}$

Tabel 1 Data Hasil Penentuan Aktivitas Amilase, Kadar Protein dan Aktivitas Spesifik Amilase Ekstrak Kasar.

\begin{tabular}{lccc}
\hline \multicolumn{1}{c}{ Sampel } & $\begin{array}{c}\text { Unit Aktivitas } \\
(\text { Unit/mL) }\end{array}$ & $\begin{array}{c}\text { Kadar Protein } \\
\text { Total }(\mathrm{mg} / \mathrm{mL})\end{array}$ & $\begin{array}{c}\text { Aktivitas Spesifik } \\
\text { enzim }(\mathrm{U} / \mathrm{mg})\end{array}$ \\
\hline $\begin{array}{l}\text { Supernatan bening } \\
\text { Supernatan keruh }\end{array}$ & 3,19 & 0,57 & 5,56 \\
\hline
\end{tabular}

Tabel 2 Data Hasil Penentuan Aktivitas Amilase, Kadar Protein, dan Aktivitas Spesifik Amilase setelah Fraksinasi dan Dialisis.

\begin{tabular}{ccccc}
\hline Sampel & $\begin{array}{c}\text { Tingkat } \\
\text { Kejenuhan } \\
\text { Ammonium } \\
\text { Sulfat }\end{array}$ & $\begin{array}{c}\text { Unit Aktivitas } \\
(\text { Unit/mL) }\end{array}$ & $\begin{array}{c}\text { Kadar Protein } \\
\text { Total } \\
(\mathrm{mg} / \mathrm{mL})\end{array}$ & $\begin{array}{c}\text { Aktivitas Spesifik } \\
\text { enzim (U/mg) }\end{array}$ \\
\hline Ekstrak & $50 \%$ & 7,97 & 0,662 & 12,04 \\
\cline { 2 - 5 } Enzim & $55 \%$ & 7,33 & 0,009 & 826,35 \\
\cline { 2 - 5 } & $60 \%$ & 10,23 & 0,005 & 1959,75 \\
\hline
\end{tabular}


sambil diaduk menggunakan magnetic stirer pada suhu $5{ }^{\circ} \mathrm{C}$. Setelah beberapa jam diaduk akan mencapai kesetimbangan (konsentrasi molekul kecil di dalam dan di luar membran sama, sementara molekul besar tetap berada di dalam membran). ${ }^{[10]}$ Garam ammonium merupakan molekul berukuran kecil yang akan keluar melalui pori-pori membran, sedangkan larutan enzim yang merupakan makromolekul akan tetap tertahan dalam membran.

Tiap 1 jam sekali larutan buffer fosfat harus diganti selama 3 jam, karena sebagian besar komponen buffer adalah molekul kecil yang dapat melewati pori-pori membran, sehingga larutan buffer harus diganti secara berkala. ${ }^{[7]}$ Pada Tabel 2 dapat dilihat kadar protein dan aktivitas spesifik enzim setelah dilakukan dialisis.

Setelah melalui tahap fraksinasi dan dialisis, terjadi peningkatan aktivitas spesifik enzim yaitu dari 40,14 U/mg (ekstrak enzim kasar) menjadi 826,35 U/mg (tingkat kejenuhan $55 \%$ ) dan 1959,75 U/mg (tingkat kejenuhan $60 \%$ ). Aktivitas spesifik meningkat, karena enzim yang diperoleh semakin murni.

Aktivitas spesifik enzim terbesar terdapat pada tingkat kejenuhan $60 \%$ yaitu sebesar $1959,75 \mathrm{U} / \mathrm{mg}$, sedangkan aktivitas spesifik enzim terkecil terdapat pada tingkat kejenuhan $50 \%$ yaitu sebesar 12,04 U/mg. Dalam penelitian yang dilakukan, semakin tinggi tingkat kejenuhan, semakin tinggi pula aktivitas spesifik enzim.

\section{Karakterisasi Amilase dari Biji Durian}

Penentuan $\mathrm{pH}$ optimum amilase dilakukan sesuai dengan prosedur uji aktivitas amilase. Pati yang ditambahkan saat uji aktivitas dilarutkan ke dalam buffer fosfat dengan berbagai $\mathrm{pH}(5,6$, dan 7$)$. $\mathrm{pH}$ optimum amilase dari tumbuhan berkisar antara $\mathrm{pH}$ 5,46,2 , sehingga untuk menetukan $\mathrm{pH}$ optimum amilase pada biji durian digunakan rentang $\mathrm{pH}$ antara 5-7.

Penentuan suhu optimum dilakukan dengan menginkubasi larutan enzim dan pati dalam buffer fosfat $\mathrm{pH}$ optimum. Sebelum diukur absorbansinya, campuran enzim dan pati diinkubasi dalam berbagai suhu $(30,40,50,60$, dan $70{ }^{\circ} \mathrm{C}$ ). Suhu dengan aktivitas spesifik terbesar inilah yang disebut suhu optimum amilase.

\section{pH Optimum}

Aktivitas spesifik amilase dari biji durian meningkat drastis pada $\mathrm{pH} 6$ dan menurun pada pH 7 seperti yang ditunjukkan pada Gambar 1. Aktivitas spesifik amilase yang diperoleh pada pH 6 sebesar 301,19 U/mg.

Enzim memiliki gugus aktif yang bermuatan positif dan negatif. Aktivitas enzim akan optimum jika terdapat keseimbangan antara kedua muatannya. Pada keadaan asam, enzim mengalami protonasi dan kehilangan muatan negatifnya. Hal yang sama pada $\mathrm{pH}$ basa substrat akan terionisasi dan kehilangan muatan positifnya, sehingga aktivitas enzim berkurang dan bahkan menjadi tidak aktif. ${ }^{[9]}$

Perubahan $\mathrm{pH}$ berpengaruh terhadap aktivitas enzim melalui pengubahan struktur atau muatan residu asam amino yang berfungsi dalam pengikatan substrat. $\mathrm{pH}$ yang bervariasi juga dapat menyebabkan perubahan konformasi enzim. Hal ini terjadi karena gugus

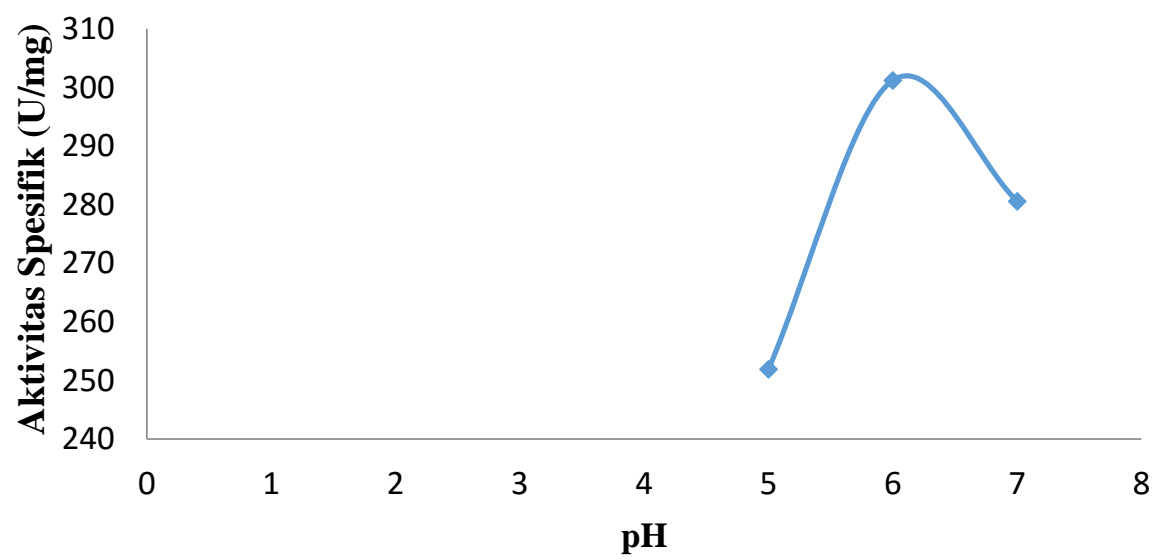

Gambar 1 Grafik pengaruh pH terhadap aktivitas spesifik amilase dari biji durian. 
bermuatan $\left(-\mathrm{NH}_{3}{ }^{+}\right.$atau $\left.-\mathrm{COO}^{-}\right)$yang jauh dari daerah terikatnya substrat, yang mungkin diperlukan untuk mempertahankan struktur tersier akan mengalami perubahan muatan pada pH yang berbeda. Hal ini akan menyebabkan terganggunya ikatan ionik dan terputusnya folding maksimum enzim sehingga konformasi enzim berubah. Perubahan konformasi enzim akan menyebabkan aktivitas enzim menjadi menurun. ${ }^{[12]}$

Aktivitas enzim berkaitan dengan strukturnya, perubahan struktur akan menyebabkan perubahan aktivitas enzim. Pada pH optimum konformasi enzim berada pada kondisi yang ideal. Hal ini menyebabkan interaksi antara enzim dan substrat menjadi maksimal. Pada suasana terlalu asam atau basa, konformasinya berubah sehingga aktivitas enzim akan terganggu. ${ }^{[3]}$

\section{Suhu Optimum}

Aktivitas spesifik amilase dari biji durian tertinggi diperoleh pada suhu $40{ }^{\circ} \mathrm{C}$ dengan aktivitas spesifik 295,25 U/mg seperti yang ditunjukkan pada Gambar 2.

Aktivitas enzim meningkat drastis pada suhu $40{ }^{\circ} \mathrm{C}$ dan menurun pada suhu $50^{\circ} \mathrm{C}$. Hal ini disebabkan pada suhu rendah reaksi kimia berlangsung lambat, sedangkan pada suhu lebih tinggi reaksi berlangsung lebih cepat. Namun kenaikan suhu dapat menyebabkan terjadinya denaturasi serta mengurangi kecepatan reaksi. Suhu optimum yaitu suhu yang menyebabkan terjadinya reaksi kimia dengan kecepatan paling besar. ${ }^{[9]}$
Sebelum mencapai temperatur $40{ }^{\circ} \mathrm{C}$ terlihat bahwa aktivitas enzim masih rendah, hal ini disebabkan pada suhu tersebut energi aktivasi yang diperlukan enzim untuk mengkatalisis reaksi hidrolisis substrat belum maksimal, sehingga enzim tidak dapat bekerja dengan baik. Kenaikan suhu menyebabkan aktivitas amilase meningkat hingga mencapai suhu optimum. Setelah mencapai kondisi optimum, terlihat bahwa aktivitas enzim menurun. Terjadinya penurunan aktivitas enzim ini karena pada suhu tinggi struktur enzim akan berubah mengalami denaturasi sehingga sisi aktif enzim akan rusak. ${ }^{[3]}$

\section{Kesimpulan}

Dari hasil penelitian ini dapat ditarik kesimpulan sebagai berikut:

1. Biji durian menghasilkan amilase dengan aktivitas spesifik sebesar 1959,75 Unit/mg,

2. Amilase dari biji durian bekerja optimum pada $\mathrm{pH} 6$ dan suhu $40^{\circ} \mathrm{C}$.

\section{Referensi}

[1] Poedjiadi A, Supriyanti T. 2005. Dasar-Dasar Biokimia. Jakarta: Universitas Indonesia (UIPress).

[2] Nurfiana F, Mukaromah U, Jeannisa VC, Putra S. 2009. Pembuatan Bioethanol Dari Biji Durian Sebagai Energi Alternatif. Teknokimia Nuklir, p. 670.

[3] Bahri S, Mirzan M, Hasan M. 2012. Karakterisasi Enzim Amilase Dari Kecambah Biji Jagung Ketan (Zea mays ceratina L.). Natural Science. vol. 1, pp. 132-143.

[4] A aC, A IU, O EC, N NF, E CU. 2009. Determination of amylase activity of crude

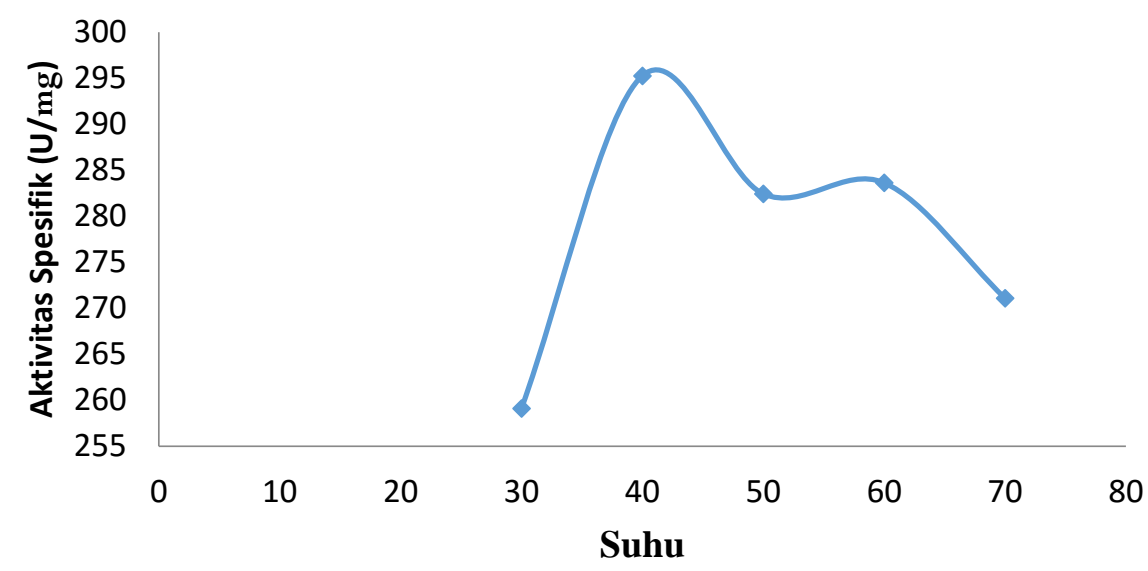

Gambar 2 Grafik pengaruh suhu terhadap aktivitas spesifik amilase 
extract from partially germinated mango seeds (Mangifera oraphila). African Journal of Biotechnology, vol. 8, p. 295.

[5] Nurachman Z, Kono A, Radjasa OK, Natalia D. 2010. Identification a Novel Raw-StarchDegrading- $\alpha$-Amylase. American Journal of Biochemistry and Biotechnology, p. 301.

[6] Anam K. 2010. Pengukuran Kadar Protein dengan Metode Bradford. Laporan Praktikum. Bogor: Sekolah Pascasarjana Institut Pertanian Bogor.

[7] Mowery J, Seidman L. Protein Purification Manual, Purification of Beta-Galactosidase from E.Coli. [Internet]. 2005 [cited 2015 Juni Selasa]. Available from: http://matcmadison.edu/biotech/

[8] Ode LS. 2012. Analisis Gelatin Sapi dan Babi dengan Perlakuan Pengendapan oleh Garam
(NH4)2SO4, pH, dan Pemanasan. Jakarta: Kementerian Agama Republik Indonesia.

[9] Mutia M, Dali S, Arfah R, Zenta F. Isolasi dan Karakterisasi Enzim Amilase dari Akar Rimpang Alang-alang (Imperata cylindrica). Penelitian Biokimia.

[10] Alzahrani Z. Salting in, salting out, dialysis of protein. [Internet]. 2009-2010 [cited 2015 Juni Minggu]. Available from: http://faculty.ksu.edu.

[11] Rahayu A. Ekstraksi Enzim Tyrosinase dari Apel Malang (Malus domestica). [Internet]. 2015 [cited 2015 Juli Kamis]. Available from: http://www.academia.edu.

[12] Masfufatun. 2013. Isolasi dan Karakterisasi Enzim Selulase. 